\title{
KNOWLEDGE AND ACCESSIBILITY OF MUSLIM WOMEN TO THE LAW ON POST-DIVORCE FINANCIAL SUPPORT
}

\author{
Muslihah Binti Hasbullah@ Abdullah,* \\ Najibah Binti Mohd Zin, ${ }^{* *}$ \\ Saodah Binti Wok ${ }^{* * *}$
}

\begin{abstract}
The main objective of the study was to determine the Muslim women's knowledge and accessibility to the law on post-divorce financial support particularly that which relates to 'iddah maintenance, mut'ah, arrears of maintenance, and child maintenance. The data was collected using self-administered questionnaire. The sample was 201 divorced women recruited from the recorded cases for the period 2003-2005 in the Shariah Subordinate Courts of Hulu Langat and Gombak Timur, Selangor. The findings indicate that almost all respondents (99\%) have high level of knowledge on the legal rights to post-divorce financial support. However, more than
\end{abstract}

Senior Lecturer, Department of Human Development \& Family Studies, Faculty of Human Ecology, University Putra Malaysia, UPM Serdang, Selangor, Malaysia.

Associate Professor, Ahmad Ibrahim Kulliyyah of Laws, International Islamic University Malaysia.

Associate Professor, Department of Communication, Kulliyyah of Islamic Revealed Knowledge \& Human Sciences, International Islamic University Malaysia. 
two-thirds of the respondents (70\%) had low level of accessibility to the law when claiming for postdivorce financial support. The study suggests that although divorced women might have better access to legal information through reading and socialization, the problems regarding the attitude of the court's officers and lawyers, the complexity of the court procedures, the uncooperative attitudes and the non-compliance of the ex-husbands to the courtordered financial support did impede their accessibility to the law.

Keywords: Accessibility, financial support, knowledge, post-divorce financial support.

\section{INTRODUCTION}

The family has always been the basic unit of a society. However, families in these days are portrayed by significant changes in terms of their composition, structure, and functions. The Department of Islamic Development of Malaysia reported that there are more than 10,000 divorce cases involving Muslims reported each year for the last decade. ${ }^{1}$ The State of Selangor still reports the highest divorce cases since 2006 compared to other States. ${ }^{2}$ In this regard, family law plays a major role not only in strengthening the family but also provides various means in minimizing the unpleasant effects of the family break up.

Provisions have been laid down in the Qur'ān that a husband should be as generous and kind as possible to his wife when divorcing her. ${ }^{3}$ This is described in terms of providing 'iddah maintenance, mut' $a h$, as well as child maintenance. ${ }^{4}$ These post-divorce financial rights may

$1 \quad$ Jabatan Kemajuan Islam Malaysia, Statistic of Muslim Divorces by States, Malaysia, http://www.islam.gov.my/informasi (accessed February 12, 2009).

$2 \quad$ Ibid.

3 Hammudah Abd al-Ati, The Family Structure in Islam (Indianapolis: American Trust Publications, 1977), p. 247.

4 Al-Qur'ān, al-Baqarah: 233, 236-237, 241-242. 
be seen as characterizing the Islamic law approach to protect the welfare of every individual in a family that breaks down. This is implemented for example by allowing a gradual release of a wife from a marital bond through her entitlement to maintenance during 'iddah period of a revocable divorce, so that she can have the chance to adjust to a new life. ${ }^{5} \mathrm{~A}$ father's responsibility to maintain his children is also retained without affecting a mother's right to custody particularly during the early years of childhood. ${ }^{6}$

However, past researches conducted in Kuala Terengganu ${ }^{7}$ and in Perlis, ${ }^{8}$ have shown that those financial rights were enforceable in a minority of divorce cases. This implies that a majority of the Muslim divorced women did not claim their rights to post-divorce financial support. A similar situation occurs in Selangor, where the 2003 statistics from the Selangor Shariah Courts ${ }^{9}$ reveal that out of 3,005 cases of divorce registered with the court, there were only 108 cases on mut ' $a$ h, 72 cases on 'iddah maintenance, 30 cases on arrears of maintenance and 180 cases on child maintenance. The statistics also disclose that some claims for financial support had been withdrawn involving 7 cases for mut 'ah, 5 cases for 'iddah maintenance, 1 case for arrears of maintenance and 10 cases for child maintenance. This record shows that though thousands of women are being divorced every year, they are not getting their due share of maintenance and mut 'ah and also child maintenance for the benefit of their children, although these rights have been granted to them under the Islamic family law.

5 Al-Qur'ān, al-Ṭalāq: 6; See also Muhammad Ibn 'Alī al-Shaukānī Nayl al-Awtār, vol. 6 (Kaherah: Maktabah Dār al-Turāth, 1938), p. 219 on hadith regarding Hind bint 'Utbah, which reflected the obligation of a husband to provide reasonable maintenance to his wife.

$6 \quad$ Muhammad Ibn 'Alī al-Shaukānī, Nayl al-Awtāôr, vol. 6 (Kaherah: Maktabah Dār al-Turāth, 1938), pp. 326-331; See also Muhammad Abu Zahra, "Family Law." In Law in the Middle East: Origin and Development of Islamic Law, ed. Majid Khadduri and Herbert J. Liebesny, vol. 1 (New York: AMS Press, 1955), pp.151-152. Salleh Ismail, Pembubaran Perkahwinan Mengikut Fiqh dan Undangundang Keluarga Islam (Kuala Lumpur: DBP, 2003), p. 215.

$8 \quad$ Raihanah Abdullah (ed.), "Wanita, Perceraian dan Mahkamah Syariah." In Wanita dan Perundangan Islam (Kuala Lumpur: Ilmiah Publisher, 2001), pp. 94-120.

9 Statistics of Mal Cases, Jabatan Kehakiman Shariah Selangor. 
Local research findings indicate that many Muslim women are ill-informed about their legal rights after divorce. ${ }^{10}$ It is evident that many divorced women agreed to forego their financial rights by accepting "consent judgment” in order to get divorced. ${ }^{11}$ Consequently, they could not claim their rights to financial support later on, although such rights are guaranteed by the Islamic law. ${ }^{12}$ It is unfortunate that such "consent" had been recorded by the court without taking into account the deprived economic conditions that might be faced by the women, particularly those who have no work experience and left without income. Another research conducted by the Women's Crisis Centre in Penang examined the cases and judgments of the Shariah Courts of Kuala Lumpur, Johor Bahru, and Penang. ${ }^{13}$ The study found that the women had to face injustice and obstacles especially in their applications for divorce and enforcement of maintenance orders by the court. ${ }^{14}$ It is unfortunate that all these problems and dilemmas still occur despite the number of significant amendments that have been made to improve the administration of Islamic law of marriage and divorce over the years.

\section{OBJECTIVES OF STUDY}

In view of the increasing number of the Muslim divorced women in Malaysia, their ignorance about their legal rights after divorce, and the

$10 \quad$ Salleh Ismail, n. 7, p. 215; Rozi Bainon, Wanita: Penghapusan Diskriminasi dari Perspektif Islam dan Undang-undang Malaysia (Kuala Lumpur: DBP, 2003), p. 84.

$11 \quad$ Raihanah Abdullah, n. 8, p. 110.

$12 \quad$ Ibid, p. 111.

13 As cited in Maznah Mohammad, "Di Mana Berlaku Diskriminasi Dalam Undang-undang Keluarga Islam.” In Undang-undang Keluarga Islam dan Wanita di Negara-negara ASEAN, ed. Abdul Monir Yaacob (Kuala Lumpur: IKIM, 1999), pp. 237-261.

$14 \quad I b i d$. See also examples of newspaper reports addressing these problems. "Selesaikan Segera Kes Perceraian Tertangguh - MB," Mingguan Malaysia, July 22, 2006, p. 14; "Ramai Wanita Tak Didedah Undang-undang Islam,” Berita Harian, August 4, 2006, p. 7; “Takrim Galak Pasangan Suami Isteri Menabung,” Berita Harian, October 31, 2006, p. 12. 
problems with the legal process that they have to face while claiming for post-divorce financial support, the current study aims to achieve four objectives i.e., (i) to describe the respondents' demographic characteristics; (ii) to describe the respondents' divorce context; (iii) to determine the respondents' knowledge on the law of financial support; and (iv) to determine the respondents' accessibility to the law on financial support.

\section{METHODOLOGY}

The survey research method, the most popular data-gathering technique in marriage and family studies ${ }^{15}$ was used in this study. The population of the study consisted of 983 Muslim divorced women recruited from the recorded cases from the year of 2003 to 2005 in two Shariah Subordinate Courts in Selangor, which were the Shariah Subordinate Court of Gombak Timur and the Shariah Subordinate Court of Hulu Langat. The accessible population identified for the study was the divorced women who had claimed for post-divorce financial support in terms of 'iddah maintenance, mut' $a h$, arrears of maintenance, and child maintenance.

\section{Sample}

About 20\% of the respondents were randomly selected from the list of names that have complete addresses and 201 of them were accessible and agreed to be recruited for the study. Of the total of 201 respondents, 135 of them were retrieved from the Shariah Subordinate Court of Gombak Timur and the rest (66 respondents) were from the Shariah Subordinate Court of Hulu Langat.

$15 \quad$ B. Strong, C. De Vault, B.W. Sayad, and T.F Cohen, The Marriage and Family Experience, $8^{\text {th }}$ Edition (California: Wadsworth/Thompson Learning, 2001), pp. 41-42. 


\section{Data Collection}

The data was collected using the self-administered questionnaire. The questionnaires were distributed personally to the respondents based on their residences' addresses. As most of the respondents were employed during the time of the survey the questionnaires could only be distributed during weekends. Informed consent was obtained from each respondent by showing the letter of permission to conduct the survey. The responses from the respondents were prompt and small souvenirs were presented as tokens of appreciation.

\section{Research Instrument}

The research instruments used in this study were designed in the native language, Bahasa Malaysia.

Demographic characteristics. The questions were intended to gather information about the respondents' age, level of education, employment status, monthly income, and number of dependants.

Divorce Context. The respondents were asked whether they had claimed any post-divorce financial support such as 'iddah maintenance, mut ' $a$, arrears of maintenance, and child maintenance. The respondents were requested to state the amount of financial support received from the exhusband, if any.

Knowledge on the Legal Rights to Financial Support. Knowledge (thirty-five items) was measured by asking the respondents to indicate on a two-point scale $(0=$ No, $1=$ Yes) about general knowledge on the legal right to financial support; specific rights to 'iddah maintenance; mut 'ah, arrears of maintenance; and child maintenance, common financial support as well as the methods of enforcing the court-ordered financial support. The cumulative score was divided into two categories based on the calculated median, i.e., those who scored from 1 to 18 were considered as having low knowledge while those who scored from 19 to 35 fell into the group of high knowledge. The minimum score was 0 and the maximum score was 35. The higher the total score correlates with higher level of knowledge. The questions were self-developed by the researcher based 
on the Islamic Family Law (Federal Territories) Act 1984 (IFLA 1984), the literature reviewed, and consultation with the experts.

Accessibility to the Law on Financial Support. Accessibility (sixteen items) was measured by asking the respondents to indicate on a twopoint scale $(0=$ No, $1=$ Yes $)$ about effort made to access the law on financial support; sources of information; and problems faced on financial support. The cumulative score was categorized into two groups based on the calculated median, i.e., those who scored from 1 to 8 were considered of having low accessibility while those who scored from 9 to 16 fall into the group of high accessibility. The higher the total score means the respondents have higher level of accessibility. The minimum score was 0 and the maximum score was 16 . Scores for 7 items on the problems of financial support faced by the respondents were reversed before summing all the items to yield a total score. The questions were self-developed by the researcher based on the IFLA 1984, the literature reviewed, and consultation with the experts.

\section{RESULTS OF THE STUDY}

\section{Demographic Characteristics}

Age. The respondents' age range was from 23 to 70 years old (Table 1). About 20\% of the respondents were aged less than or equal to 30 years old. About two-fifth of the respondents (40\%) were between 31 to 40 years old. Another $30 \%$ of the respondents were between 41 to 50 years old. The rest (10\%) of the respondents were aged more than 51 years old. The respondents' average age in the study was 38.68 years and the standard deviation was 8.75 .

Education. Only one respondent claimed that she had no formal education. About $7 \%$ of the respondents completed their primary education. More than two-thirds of the respondents (68\%) completed their secondary school either at SRP (lower secondary certificate) or SPM (upper secondary certificate) level. About $6 \%$ of them completed their STPM level. Another $13 \%$ of the respondents obtained their 
Diploma. About $6 \%$ of the respondents obtained their Bachelor Degree, and the rest (1\%) obtained their Master Degree.

Employment Status. A majority of the respondents (80\%) were employed, while the rest (20\%) were unemployed. This is consistent with the respondents' mean age in this study which was about 39 years old, i.e. they were within the working age population for the Malaysian women of 15-64 years. ${ }^{16}$ The reason for those who were unemployed might be due to their low level of educational attainment.

Monthly Income. Almost one-fifth of the respondents (18\%) had no income. About $28 \%$ of the respondents earned less than RM1,000. Another $46 \%$ of the respondents earned between RM1,001 to RM3,000. The rest of the respondents (7\%) earned more than RM3,001. Those who had no income were excluded from the analysis. As such, the average income was RM1,707.21 and the standard deviation was RM1,797.21.

Number of Dependant. About $16 \%$ of the respondents had no dependant. More than half of the respondents (57\%) had 1 to 2 dependants, while another $22 \%$ of them had 3 to 4 dependants. Only $5 \%$ had 5 dependants. While excluding those who had no dependant from the analysis, the average number of dependants was 2.72 and the standard deviation was 1.46. The result was about the same as the average size of the Malaysian family i.e. $2.76 .{ }^{17}$

Table 1:

Demographic Characteristics of the Respondents

Demographic Characteristics Frequency Percentage

Age (years):

$\begin{array}{lll}<30 & 41 & 20.4 \\ 31-40 & 80 & 39.8 \\ 41-50 & 61 & 30.3\end{array}$

\footnotetext{
16 Economic Planning Unit, Ninth Malaysia Plan 2006-2010, http:// www.epu.jpm.my (accessed July 2, 2009).

$17 \quad$ Ibid.
} 


\begin{tabular}{|c|c|c|}
\hline$>51$ & 19 & 9.5 \\
\hline Total & 201 & 100.0 \\
\hline \multicolumn{3}{|l|}{ Mean $=38.68, \mathrm{SD}=8.75$} \\
\hline \multicolumn{3}{|l|}{ Level of Education: } \\
\hline No formal education & 1 & 0.5 \\
\hline Primary education & 13 & 6.5 \\
\hline SRP & 29 & 14.4 \\
\hline SPM & 107 & 53.2 \\
\hline STPM & 11 & 5.5 \\
\hline Diploma & 27 & 13.4 \\
\hline Bachelor's Degree & 11 & 5.5 \\
\hline Master’s Degree & 2 & 1.0 \\
\hline Total & 201 & 100.0 \\
\hline \multicolumn{3}{|l|}{ Employment Status: } \\
\hline Working & 160 & 79.6 \\
\hline Not working & 41 & 20.4 \\
\hline Total & 201 & 100.0 \\
\hline \multicolumn{3}{|l|}{ Monthly Income: } \\
\hline $\mathrm{RM0}$ & 37 & 18.4 \\
\hline RM1 - RM1,000 & 57 & 28.4 \\
\hline RM1,001-RM3,000 & 93 & 46.2 \\
\hline RM3,001 - RM5,000 & 12 & 6.0 \\
\hline RM5,001 - RM7,000 & 1 & 0.5 \\
\hline$>\mathrm{RM} 7,001$ & 1 & 0.5 \\
\hline Total & 164 & 81.6 \\
\hline \multicolumn{3}{|l|}{ Mean $=1707.21, \mathrm{SD}=1797.21$} \\
\hline \multicolumn{3}{|l|}{ Dependant (Children): } \\
\hline 0 & 33 & 16.4 \\
\hline $1-2$ & 115 & 57.2 \\
\hline $3-4$ & 44 & 21.9 \\
\hline 5 & 9 & 4.5 \\
\hline Total & 186 & 83.6 \\
\hline Mean $=2.72, \mathrm{SD}=1.46$ & & \\
\hline
\end{tabular}

\section{Divorce Context}

Claims for Iddah Maintenance. A majority of the respondents (89\%) claimed for 'iddah maintenance from their ex-husbands (Table 2). Unfortunately, $11 \%$ of the respondents did not claim. Among those who claimed for 'iddah maintenance, $44 \%$ received nothing from their exhusbands. About $46 \%$ of the respondents received less than RM1,000 
and only 7\% received between RM1,001 to RM2,000. The rest (3\%) received more than $\mathrm{RM} 2,000$. The average amount of 'iddah maintenance received was RM823.10 and the standard deviation was RM690.26.

Claims for Mut'ah. More than half of the respondents (55\%) claimed for mut ' $a$ h, while another $45 \%$ did not claim. Among those who claimed for mut'ah, more than two-thirds of the respondents (67\%) received nothing from their ex-husbands. About $14 \%$ of the respondents received less than RM1, 000 and another 9\% received between RM1,001 to RM2,000. The rest (10\%) received more than RM2,000. The average amount of mut'ah was RM2,279.17 and the standard deviation was RM2,794.93.

Claims for Arrears of Maintenance. Only 20\% of the respondents claimed for arrears of maintenance. A majority of them (80\%) did not claim. Among those who claimed, more than half (58\%) received nothing from their ex-husbands. About $18 \%$ of the respondents received less than RM1,000. Another 13\% received between RM1,001 to RM2,000. The rest (8\%) received more than RM2,000. The average amount of arrears of maintenance was RM1,811.76 and the standard deviation was RM1,288.35.

Table 2:

Divorce Context of the Respondents

\begin{tabular}{lll}
\hline Divorce Context & Frequency & Percentage \\
\hline Claims for 'Iddah Maintenance: & & \\
\hline Yes & 179 & 89.1 \\
No & 22 & 10.9 \\
Total & $\mathbf{2 0 1}$ & $\mathbf{1 0 0 . 0}$ \\
\hline Amount of 'Iddah Maintenance: & & \\
\hline RM0 & 79 & 44.1 \\
RM1-RM1,000 & 82 & 45.8 \\
RM1,001-RM2,000 & 13 & 7.3 \\
RM2,001-RM3,000 & 4 & 2.2 \\
>RM3,001 & 1 & 0.6 \\
Total & $\mathbf{1 0 0}$ & 55.9 \\
Mean = 823.10, SD =690.26 & & \\
\hline
\end{tabular}

Claims for Mut'ah: 


\begin{tabular}{|c|c|c|}
\hline Yes & 110 & 54.7 \\
\hline No & 91 & 45.3 \\
\hline Total & 201 & 100.0 \\
\hline \multicolumn{3}{|l|}{ Amount of Mut'ah: } \\
\hline$\overline{\mathrm{RM} 0}$ & 74 & 67.3 \\
\hline RM1 - RM1,000 & 15 & 13.6 \\
\hline RM1,001-RM2,000 & 10 & 9.1 \\
\hline RM2,001 - RM3,000 & 6 & 5.5 \\
\hline$>$ RM3,001 & 5 & 4.5 \\
\hline Total & 36 & 32.7 \\
\hline \multicolumn{3}{|l|}{ Mean $=2279.17, \mathrm{SD}=2794.93$} \\
\hline \multicolumn{3}{|c|}{ Claims for Arrears of Maintenance: } \\
\hline Yes & 40 & 19.9 \\
\hline No & 161 & 80.1 \\
\hline Total & 201 & 100.0 \\
\hline \multicolumn{3}{|c|}{ Amount of Arrears of Maintenance: } \\
\hline$\overline{\mathrm{RM} 0}$ & 23 & 57.5 \\
\hline RM1 - RM1,000 & 7 & 17.5 \\
\hline RM1,001-RM2000 & 5 & 12.5 \\
\hline RM2,001 - RM3,000 & 3 & 7.5 \\
\hline$>$ RM3,001 & 2 & 5 \\
\hline Total & 17 & 42.5 \\
\hline \multicolumn{3}{|l|}{ Mean $=1811.76, \mathrm{SD}=1288.35$} \\
\hline \multicolumn{3}{|l|}{ Claims for Child Maintenance: } \\
\hline Yes & 148 & 73.6 \\
\hline No & 53 & 26.4 \\
\hline Total & 201 & 100.0 \\
\hline \multicolumn{3}{|l|}{ Amount of Child Maintenance: } \\
\hline $\mathrm{RM} 0$ & 14 & 9.5 \\
\hline RM1 - RM500 & 122 & 82.4 \\
\hline RM501-RM1,000 & 10 & 6.7 \\
\hline >RM1001 & 2 & 1.4 \\
\hline Total & 134 & 90.5 \\
\hline Mean $=271.75, \mathrm{SD}=230.48$ & & \\
\hline
\end{tabular}

Note. $\mathrm{RM0}=$ missing value, thus it was excluded from the analysis

\section{Claims for Child Maintenance}

Almost three quarters of the respondents (74\%) claimed for child maintenance, while another $26 \%$ did not claim. Among those who claimed, about $10 \%$ received nothing from their ex-husbands. The 
majority of the respondents (82\%) received less than RM500 per month as child maintenance. Another $7 \%$ of the respondents received between RM501 and RM1,000. Only two respondents received more than RM1,001. The average amount of child maintenance was RM271.75 and the standard deviation was RM230.48.

\section{Respondents' Knowledge on the Legal Rights to Post-Divorce Financial Support}

Almost all respondents (99\%) generally knew that a woman who has been divorced is entitled to claim for financial support in the Shariah Court (Table 3). The respondents (99\%) also knew that they had the right to complain to the Shariah Court when the ex-husbands defied the court order. About $97 \%$ of the respondents knew that they could claim financial support with the help of a legal practitioner from the Legal Aid Bureau, and 96\% of them also knew that they could hire a Shar'i lawyer for the same matter.

Table 3:

\section{Respondents' Knowledge on the Legal Rights to Financial Support $(\mathbf{N}=\mathbf{2 0 1})$}

\begin{tabular}{lr}
\hline Knowledge on the Legal Rights to Financial Support & $\mathbf{\%}$ \\
\hline General Knowledge on the Legal Rights to Financial Support: & \\
\hline $\begin{array}{l}\text { A divorced woman can claim financial support in the Shariah Court } \\
\text { Right to complain to the Shariah Court when the ex-husband defied } \\
\text { court order }\end{array}$ & 99.5 \\
$\begin{array}{l}\text { A lawyer from Legal Aid Bureau can claim financial support on behalf } \\
\text { of a divorced woman }\end{array}$ & 99.0 \\
$\begin{array}{l}\text { A Shar'i lawyer can claim financial support on behalf of a divorced } \\
\text { woman }\end{array}$ & 96.5 \\
\hline $\begin{array}{l}\text { Right to 'Iddah Maintenance: } \\
\text { A divorced woman is entitled to claim 'iddah maintenance }\end{array}$ & 96.0 \\
\hline $\begin{array}{l}\text { A divorced woman is entitled to be maintained by the ex-husband } \\
\text { during 'iddah only }\end{array}$ & 99.5 \\
$\begin{array}{l}\text { A divorced woman is entitled to 'iddah maintenance if she is not } \\
\text { nushüz }\end{array}$ & 98.5 \\
\hline
\end{tabular}

Right to Mut'ah:

Every divorced woman is entitled to claim for mut $^{\prime} a h$ 


\section{Right to Arrears of Maintenance:}

A divorced woman can claim for arrears of maintenance

Right to Child Maintenance:

A divorced woman is entitled to claim for child maintenance

A father is obliged to provide/pay for cost of his child's accommodation 98.5

A father's obligation to maintain continues if the child is under physical or mental disability

A father is obliged to provide/pay for his child's clothing

A father is obliged to provide/pay for his child's food

A father is obliged to provide/pay for cost of his child's medical expenses

A father is obliged to provide/pay for cost of his child's education $\quad 97.0$

Right to vary a child maintenance order

A father's obligation to maintain continues when the child pursues his education

A father's obligation to maintain continues until the child reaches 18 years of age

A father's obligation to maintain continues if the daughter is unmarried 90.0 When the father is unable to maintain his child, his relatives can be held liable to maintain the child

When the father's whereabouts is unknown, his relatives can be held liable to maintain the child

\section{Common Financial Support:}

A divorced woman is entitled to claim for accommodation during 'iddah

Right to accommodation ceases when guilty of open lewdness

A divorced woman is entitled to claim for accommodation during guardianship period

Right to accommodation ceases when she remarries

A divorced woman can claim for interim maintenance

Right to accommodation ceases after 'iddah expires

56.2

Right to accommodation ceases after guardianship expires

50.2

\section{Methods of Enforcing Court-ordered Financial Support:}

Shariah Court can order the ex-husband to pay financial support in instalments

Shariah Court can attach the earnings of the ex-husband to ensure that he pays the financial support

Shariah Court can order the ex-husband to pay financial support in a lump sum.

Shariah Court can order the ex-husband to make payment for financial support into Court

Shariah Court can order the ex-husband to deposit the payment into the ex-wife's account 
Shariah Court can make a committal order against the default exhusband 77.6

Regarding the right to claim for 'iddah maintenance, 99\% of the respondents knew that they were entitled to claim for such right under the Islamic law, and it has to be provided by the ex-husband during the period of 'iddah only. About $96 \%$ of the respondents knew that if they were found to be recalcitrant (nushüz) towards the lawful wishes of the husbands, they were not entitled to 'iddah maintenance. About $94 \%$ of the respondents knew that a divorced woman was entitled to claim mut'ah, while $96 \%$ of them knew about their right to claim for any maintenance that fell into arrears.

Almost all respondents (99\%) knew that a divorced custodial mother had the right to claim for child maintenance against the child's father, and the latter should provide or pay for the cost of the child's accommodation too. About $98 \%$ of the respondents knew that the father is continuously obliged to maintain his child who is suffering from a physical or mental disability. Regarding the types of child maintenance, 98\% of the respondents knew that it would include providing food and cloth or paying for its costs and $97 \%$ knew that it included paying for medical expenses and education. About $96 \%$ of the respondents knew that they could apply for a variation of the child maintenance order when circumstances arise. For example, when a child has grown up, he will need more money for education, thus the mother may apply to the court for an increment of the child maintenance against the child's father.

Among the respondents, 95\% knew that a father is obliged to continuously maintain a child who is beyond 18 years old when the latter is pursuing his education. About $91 \%$ of the respondents knew that child maintenance is to be provided by a father until the child reaches 18 years old and 91\% knew that the father's obligation will continue if he has an unmarried daughter. However, only 58\% knew about the extent of liability of the ex-husbands' relatives to contribute to child maintenance, such as when the whereabouts of the child's father is unknown or when the latter is financially unable to maintain his child.

Common matters to financial rights after divorce include the right to accommodation and claim for an interim maintenance. Among the respondents, 96\% knew that a divorced woman has a right to accommodation in the matrimonial home during the 'iddah period. About $93 \%$ of them knew that a divorced woman is also entitled to occupy the 
home during the period of guardianship of the child and such right will cease if she is found guilty of open lewdness. Among the respondents, $92 \%$ knew that the right to accommodation will also cease when a divorced woman remarried, while $85 \%$ knew about the right to apply to the court for interim maintenance. About $56 \%$ of the respondents knew that the right to accommodation ceases when 'iddah period expires and only $50 \%$ of the respondents knew that such right will also terminate after the period of guardianship of the child expires.

The majority of the respondents had the knowledge regarding several methods used by the Shariah court to ensure that the ex-husband complied with the court-ordered post-divorce financial support. In particular, 98\% of the respondents knew that the Shariah judge can order a man to pay financial support in instalment, while $97 \%$ knew that it can be done through attachment of the ex-husbands' earnings. About $94 \%$ of the respondents knew that financial support can be ordered to be paid in a lump sum or the payment can be made into court. About $91 \%$ of the respondents knew that the Shariah judge can also order the ex-husbands to deposit the money into the respondents' account. However, only about $78 \%$ of them knew about the power of the Shariah court to make a committal order against defaulting ex-husbands.

The cumulative scores of the respondents' knowledge on the legal rights to post-divorce financial support were grouped into two categories, which were high knowledge, and low knowledge (Table 4). Almost all respondents (99\%) had high level of knowledge on the legal rights to post-divorce financial support. Their total scores ranged from 19 to 35. Only one respondent had low level of knowledge as her total score was 18. The mean knowledge score was 31.62 and the standard deviation was 3.13, which indicates that the respondents acquired good level of knowledge on the legal rights to post-divorce financial support.

Table 4:

Categories of the Respondents' Knowledge

\begin{tabular}{lll}
\hline Level of Knowledge & Frequency & Percentage \\
\hline High Knowledge $(19-35)$ & 200 & 99.5 \\
Low Knowledge $(1-18)$ & 1 & 0.5 \\
Total & $\mathbf{2 0 1}$ & $\mathbf{1 0 0 . 0}$ \\
Mean $=$ 31.62, SD $=3.13$ & & \\
\hline
\end{tabular}




\section{Respondents' Accessibility to the Law on Post-Divorce Financial Support}

Regarding the effort made by the respondents to access the law on financial rights after divorce, $45 \%$ of them claimed that they had attended courses on the rights and responsibilities in a marriage (Table 5). Another $36 \%$ of the respondents claimed that they had hired lawyers to help them in claiming financial support.

The majority of the respondents (80\%) claimed that their accessibility to information on financial support were from officers of the Islamic Religious Department. More than two-thirds of the respondents obtained information on financial support from relatives (68\%), and books or newspapers (67\%). More than half of the respondents (59\%) obtained information on financial support from the electronic media. Another more than two-fifths (45\%) resorted to their neighbours or friends for information on financial support. More than one-third of the respondents (39\%) obtained information from lawyers. The rest (24\%) obtained information from related seminars or talks that they had attended.

More than two-thirds of the respondents (64\%) claimed their ex-husbands did not co-operate to settle the case. More than half of the respondents (58\%) claimed their ex-husbands did not comply with financial support court orders. Two-fifths of the respondents (40\%) claimed that they had to face a long and exhausting hearing of cases. More than onethird of the respondents (36\%) claimed that their cases had been frequently postponed. The rest, less than one-third claimed that the court procedures were unclear (30\%); the lawyers were inefficient in handling the case (18\%); and the court officers were unfriendly (17\%).

Table 5:

Respondents' Accessibility to the Law on Financial Support $(\mathrm{N}=\mathbf{2 0 1})$

Accessibility to the Law on Financial Support $\%$ Effort Made to Access the Law on Financial Support:

Attend any course on rights and responsibilities in a marriage/after divorce

Get a lawyer to claim for financial support after divorce 


\begin{tabular}{lc}
\hline Sources of Information: & \\
\hline Information on financial support from officers of Islamic Religious & \\
Department & 80.1 \\
Information on financial support from relatives & 68.2 \\
Information on financial support available in books/newspapers & 66.7 \\
Information on financial support available on electronic media & 59.2 \\
Information on financial support from neighbours/friends & 45.3 \\
Information on financial support from lawyer & 39.3 \\
Information on financial support from seminars/talks & 24.4 \\
\hline Problems Faced on Financial Support: & 64.2 \\
\hline Ex-husband does not co-operate to settle the case* & 57.7 \\
Ex-husband does not comply with court order* & 39.3 \\
Long and exhausting hearing of case* & 36.3 \\
Frequent postponement of case* & 29.4 \\
Shariah Court procedures are unclear and complex* & 17.9 \\
Lawyers' inefficiency* & 17.4 \\
\hline Shariah Court officers are unfriendly* &
\end{tabular}

Note. *- Reversed items

The cumulative scores of the respondents' accessibility to the law on post-divorce financial support were divided into two categories, which were high, and low accessibility. Table 6 shows that more than two-thirds of the respondents (70\%) claimed they had low level of accessibility to the law when claiming for their rights to financial support. The rest (30\%) of them claimed that they had high accessibility to the law on financial support. As the mean accessibility was 6.81 and the standard deviation was 3.07, the respondents in this study were found to have low level of accessibility to the law on post-divorce financial support.

Table 6:

Categories of the Respondents' Accessibility

\begin{tabular}{lll}
\hline Level of Accessibility & Frequency & Percentage \\
\hline High accessibility $(9-16)$ & 60 & 29.9 \\
Low accessibility $(0-8)$ & 141 & 70.1 \\
Total & $\mathbf{2 0 1}$ & $\mathbf{1 0 0 . 0}$ \\
Mean $=6.81, \mathrm{SD}=3.07$ & & \\
\hline
\end{tabular}




\section{DISCUSSION OF THE RESULTS}

The findings of this study indicate that the majority of the divorced women had a high knowledge regarding their legal rights to post-divorce financial support. Particularly, they were very familiar with their rights to claim for 'iddah maintenance, mut'ah, arrears of maintenance and child maintenance. They were also aware of their rights to other types of financial protection under the Malaysian Islamic Family Law such as the right to claim for an interim maintenance and the right to accommodation. They were also acquainted with the factor that denies their rights to 'iddah maintenance such as the offence of nushüz. On top of that, they were aware of the methods of enforcing court-ordered post-divorce financial support, such as attachment of earnings order, payment by instalments, lump sum payment, payment into court or into the ex-wife's account, and an order of committal, which may lead to imprisonment. The apparent results might be due to the fact that the majority of the respondents were literate and employed. This implies that they might have better access to legal information through readings and socialization.

Though many divorced women were aware of their financial rights after divorce, some were still unaware of certain specific rights available under the Islamic law. It was found that half of the respondents did not know about their right to accommodation during 'iddah period. Therefore, many divorced women left their matrimonial homes while they were observing ' $i d d a h$ period..$^{18}$ In addition, they were also unaware about the availability of the legal provisions on the liability of the exhusbands' relatives in contributing to the maintenance of children particularly when the whereabouts of the child's father is unknown or he is unable to provide maintenance. ${ }^{19}$ This situation contributes to the nonpayment or inadequate payment of child maintenance provided by the ex-husbands, and these factors intensify the economic difficulties of divorced women as they face conflicting demands of employment and parenting responsibilities. ${ }^{20}$

\footnotetext{
$18 \quad$ Salleh Ismail, n. 7, pp. 155, 216.

19 IFLA 1984, s 72(2).

20 Constance L. Shehan, Marriage and Families, $2^{\text {nd }}$ Edition (Boston: Allyn \& Bacon, 2003), p. 388.
} 
Therefore, the above findings partially oppose the general assumptions or allegations made in scholarly works ${ }^{21}$ or local newspaper reports $^{22}$ that many women are ignorant about their rights under the Islamic Family Law and the rights to post-divorce financial support.

The results also indicate that the respondents had low accessibility to the law on post-divorce financial support. However, the majority of them obtained information on financial rights from the officers of the Islamic Religious Department. The finding support previous research, which indicated that many women became familiar with the Islamic Religious Department once they were faced with marital crises as it was the only place that they visited. ${ }^{23}$

However, the problems regarding the attitude of the court's officers, lawyers and the complexity of the court procedures still exist despite the issues having been much highlighted in the media and discussed by the scholars. ${ }^{24}$ More particularly, the uncooperative attitudes of their ex-husbands in settling the claims for financial support and their noncompliance with financial support court orders aggravate the problems of divorced women.

It may be concluded that the above problems could have contributed to the percentage of the divorced women who did not claim their rights to 'iddah maintenance and mut' $a h$ and also refused to claim their children's right to child maintenance. On top of that, 'iddah maintenance, mut ' $a h$ and arrears of maintenance are only payable for a short period of time. If the amount is small it may be ordered by the court to be paid in a lump sum. Therefore, it might not significantly help the divorced women to improve their financial situation for a longer period after the divorce.

Salleh Ismail, n. 7, p. 215; Rozi Bainon, n. 10; Raihanah Abdullah, n. 8. See n. 14.

Maznah Mohammad, n. 14, pp. 242-243.

Zaleha Kamaruddin, "Delays in the Disposition of Matrimonial Cases in the Shariah Courts in Malaysia (1990-1997)," IIUM Law Journal 2, no. 1 (1999): 95; Maznah Mohammad, n. 14.
} 


\section{CONCLUSION}

To conclude, the laws that regulate the financial aspects of divorce merit attention from the family, the government as well as the legal professionals as they could affect the well being of every family member and also be an economic restraint against irresponsible breakdown of a marriage. This study found that although the respondents knew their rights to post-divorce financial support, they had low access to the law and were faced with several typical problems while dealing with their claims for post-divorce financial support in the Shariah Court. It is recommended that policies, which directly and indirectly affect the divorced women need to be reviewed, improved or amended in order to protect their rights as well as those of their children in the event of divorce. For example, policies should be more comprehensive in terms of providing for a life-long education for Muslim women and men with regard to their rights and responsibilities during marriage and after divorce; enhancing the administrative machinery of the judicial system; constructing guidelines in assessing the reasonable amount of financial support; and legislating for more effective methods of enforcement and execution of court orders.

As the sample in the present study was limited to divorced women, it is recommended that future study may include some proportions of the ex-husbands while assessing the same key variables on post-divorce financial support. This will enable an examination of differences associated with gender. As the respondents' level of knowledge and accessibility to post-divorce financial support may differ by geographical locations, a future study may be conducted in rural areas such as in Kelantan, Terengganu, Sabah or Sarawak. The evidence that will be accumulated from the sample in the rural areas will be critical to the continuing process of protecting the divorced women's welfare through the post-divorce financial support mechanism. 
